\title{
Marine bacteria from the Gulf of California with antimicrofouling activity against colonizing bacteria and microalgae
}

\author{
Diana Elizabeth Sánchez-Rodríguez ${ }^{1}$, Ismael Ortiz-Aguirre² ${ }^{2}$ Ruth Noemí Aguila-Ramírez ${ }^{3 *}$, \\ Erika Guadalupe Rico-Virgen ${ }^{1}$, Bárbara González-Acosta ${ }^{3}$ \& Claire Hellio ${ }^{4}$ \\ 1. Universidad de Guadalajara. CUCSur, Gómez Farías 82. San Patricio Melaque, Jalisco, México; \\ sanchez.rodriguez08@gmail.com, erilups.rivir@gmail.com \\ 2. Universidad Autónoma de Baja California Sur, Carretera al Sur Km 5.5, La Paz, Baja California Sur, México; \\ ortiz.aguirre.ismael@gmail.com \\ 3. Instituto Politécnico Nacional- Centro Interdisciplinario de Ciencias Marinas, Av. IPN S/N Col. Playa Palo de Santa \\ Rita, La Paz, Baja California Sur, México; raguilar@ipn.mx, baga.gonzal@gmail.com \\ 4. Université de Bretagne Occidentale, Biodimar/LEMAR UMR 6539, Plouzané, France; claire.hellio@univ-brest.fr \\ * Correspondence
}

Received 11-I-2018. Corrected 11-VI-2018. Accepted 06-IX-2018.

\begin{abstract}
One way of reducing the input of pollutants into the marine environment is to enforce the use of non-toxic antifouling paints in marine protected areas. Thus, the purpose of this study was to detect marine microorganisms that secrete inhibitory substances against bacteria and microalgae to avoid biofouling on manmade structures in La Paz bay, B.C.S., Mexico. The inhibitory potential of 125 bacteria was evaluated against biofilm-forming bacteria. Crude extracts were obtained with methanol and ethyl acetate from 16 bacterial strains that exhibited antagonistic and antibacterial activity in a preliminary screening. Antibacterial and antimicroalgal assays were performed using crude extracts, the minimum inhibitory concentration (MIC) was determined. The highest activity against bacteria and microalgae was found in two strains, Shewanella algae and Staphylococcus sp. The results of this study suggest that extracts of bacteria from the Gulf of California with antimicrobial properties against biofilm-forming bacteria can also prevent the adhesion of microalgae, which may control the development of biofilm formation and, as a consequence, biofouling.
\end{abstract}

Key words: epibionts; extracts; Shewanella; Staphylococcus; biofouling; antifouling.

Sánchez-Rodríguez, D. E., Ortiz-Aguirre, I., Aguila-Ramírez, R. N., Rico-Virgen, E. G., González-Acosta, B., \& Hellio, C. (2018). Marine bacteria from the Gulf of California with antimicrofouling activity against colonizing bacteria and microalgae. Revista de Biología Tropical, 66(4), 1649-1663

The biofouling process starts immediately after a substrate comes into contact with seawater. Biochemical conditioning occurs by adsorption of dissolved organic material such as polysaccharides, proteins, lipids and amino acids forming a film that enables organisms to colonize the surface (Callow \& Callow, 2011). Pioneer bacteria adhere and start forming a stratified biofilm, generating chemical signals that act as attractants or deterrents for the establishment of microalgae, spores of algae, fungi, and protozoa; then comes the settlement of invertebrate larvae, known as macrofouling (Fusetani \& Clare, 2006). This process affects the maritime industry in general, given that the establishment of micro and macroorganisms on 
man-made structures generates biocorrosion of surfaces and boats, reducing their useful life (Yebra, Kiil, \& Dam-Johansen, 2004).

Metal biocides, such as tributyltin (TBT) and copper are added to marine paints as antifouling compounds. These biocides are very toxic and affect the marine fauna; some examples include gastropod imposex, mussel larvae mortality and oyster shell malformations that have all been associated to ecotoxicological effects caused by TBT, even at extremely low concentrations (Alzieu, 2000; Konstantinou \& Albanis, 2004). Due to the environmental problems related to the use of toxic-antifouling biocides, natural alternatives are required to regulate organism-colonization processes. Therefore, given the high toxicity of antifouling paints based on chemical agents, environmentally-friendly approaches are now a priority in the search for new methods to control biofouling on surfaces. In addition, antifouling paints with toxic agents are not biodegradable, since they include organometallic compounds in their matrix (Martínez-Matamoros, 2012).

The industrial requirements for novel antifouling compounds are: absence of toxicity towards non-targeted species; several years of antifouling and anti-biocorrosion activities; no bioaccumulation in marine food webs; and containing active compounds that can be produced in large quantities by green processes (Ciriminna, Bright, \& Pagliaro, 2015). Marine bacteria are good candidates for bioactive-compound production due to their ability to generate antibacterial substances, which allow ecological stability of multiple marine ecosystems, as well as interrelationships among microorganisms in epiphytic environments (Vimala, 2016). Microbial communities have strong affinities towards living and non-living surfaces (El Bour, IsmailBen, \& Ktari, 2013), they can be cultivated in large batches and culture conditions can be modified to enhance the yield of active compounds; these characteristics comprise an environmentally friendlier process than the chemical synthesis of active compounds (Bernbom, Ng, Kjelleberg, Harder, \& Gram, 2011).
In this study, the potential of the Gulf of California as source of bioactive-bacteria strains was evaluated. Several environments and marine organisms were considered for isolation of bacteria, these included marine sediments and bacteria associated with mangrove plants. The mangrove ecosystem is a unique environment harboring diverse groups of microorganisms that play key roles in nutrient transformation (Thatoi, Behera, Mishra, \& Dutta, 2013). The degradation of mangroveplant material begins with colonization by fungi and bacteria (Grossart, Kiørboe, Tang, \& Ploug, 2003). Within this community, this is considered a selective force, a competition for resources that promotes the biosynthesis of antimicrobial compounds (Slattery, Starmer, \& Paul, 2001). Furthermore, growth processes and cell-to-cell interactions, which are regulated by signaling molecules involved in population-mediated gene expression (quorum-sensing), play an important role in the population dynamics of some bacterial species (Gomes, Grunau, Lawrence, Eberl, \& Gademann, 2003).

Some marine organisms such as sponges, seaweed and seahorses have a large number of associated bacteria, which among other functions, work as protection and defense against epibionts and other microorganisms (Hentschel et al., 2003; Balcázar, Loureiro, Da Silva, Pintado, \& Planas, 2010; Egan et al., 2013). In the marine environment, this microbial association with living surfaces (symbiosis) offers ample opportunities for bioprospection of natural products (Satheesh, Ba-akdah, \& Al-Sofyani, 2016). In some cases, bacterial symbionts are capable of producing a wide variety of bioactive compounds that prevent colonization by opportunistic or predatory organisms on the host's surface. This suggests that bioactive compounds act as antimicrobial agents. Whether as antibiotics or as inhibitors of bacterial communication systems (quorum sensing), it is expected that these microorganisms regulate the establishment of other micro and macroorganisms (Penesyan, Kjelleberg, \& 
Egan, 2010) and thus protect holobionts from epibiosis (Dobretsov, Dahms, \& Qian, 2006).

Strategies based on biomimetics have shown strong potential in solving foulingcaused problems on man-made structures. Considering that succession within the community will depend on the success of initial colonization (bacteria and microalgae), growth inhibition may be the key to control or prevent the entire process. Therefore, this research aimed to examine the effects of marine bacteria extracts against pioneer groups in the colonization process.

\section{MATERIAL AND METHODS}

Biofilm sampling from paint panels: This study was carried out during June 2016 at a marine pier in La Paz, Baja California Sur, Mexico (240' $\left.32^{\prime \prime} \mathrm{N}-110^{\circ} 18^{\prime} 39^{\prime \prime} \mathrm{W}\right)$. Three different experimental steel panels $(20 \times 10$ $\mathrm{cm})$ were used, each coated with a different paint type: Copper (C), silicon (S) and without Copper (CF). Panels were immersed to a depth of one meter below the water surface for different periods (2, 4, or $6 \mathrm{~h})$. Biofilm-forming bacteria samples were collected from each experimental panel for each period using sterile cotton swabs. These were rinsed with sterile sea water to remove the bacteria that was not adhered permanently. Samples were transferred into tubes with sterile saline solution $(\mathrm{NaCl} 2.5$ $\%)$ and transported to the laboratory.

Isolation of biofilm-forming bacterial strains on paints: The biofilm samples collected from the experimental panels were serially diluted up to $10^{-3}$. One-hundred microliters of each bacterial solution was spread on Petri dishes $(9 \mathrm{~cm})$ containing Marine Agar (MA: Peptone, Yeast extract, Sea water) and incubated at $35{ }^{\circ} \mathrm{C}$ for $24 \mathrm{~h}$. Each bacterial-colony morphotype was isolated. The biofilm-forming ability was tested for each morphotype by crystal violet assay (Martínez-Díaz, 2010; Stepanovic, Vukovic, Dakic, Savic, \& SvabicVlahovic, 2000). Strains were inoculated into Marine Broth in sterile 96-well microplate and incubated for $24 \mathrm{~h}$ at $35{ }^{\circ} \mathrm{C}$. Plate contents were poured off and the wells washed in triplicate with sterile distilled water. The remaining attached bacteria were fixed with $200 \mu \mathrm{l}$ of methanol in each well, and after $15 \mathrm{~min}$, the microplates were emptied and air dried. The microplates were stained with 200 $\mu \mathrm{l}$ of crystal violet for each well during $5 \mathrm{~min}$. Surplus stain was rinsed off by placing the microplate under running tap water. After the microplates were air dried, the dye bounded to adherent cells was resolubilized with $200 \mu \mathrm{l}$ of acetone-isopropanol (1:3) per well. The optical density (OD) of each well was measured at 620 $\mathrm{nm}$. Based on OD produced by bacterial films, strains were classified into the following categories described by Stepanovic et al. (2000): no biofilm producers and weak, moderate or strong biofilm producers.

Isolation of associated bacteria: Samples of different organisms and sediments were collected under aseptic conditions; the methodology presented in Table 1 was followed. All samples were serially diluted and spread onto Petri plates containing Marine Agar and incubated at $35{ }^{\circ} \mathrm{C}$ for $24 \mathrm{~h}$. Associated bacterial strains were isolated based on morphological characteristics, pure colonies were stored at $4{ }^{\circ} \mathrm{C}$ for further study.

Screening of marine bacteria isolates: Associated bacteria (125) were screened for antagonistic activity against six fouling bacterial strains that were isolated from the experimental panels with the double-layer technique suggested by Dopazo et al. (1988). Isolates were individually streaked on Marine Agar plates, incubated at $35^{\circ} \mathrm{C}$ for $24 \mathrm{~h}$ and overlaid using soft agar that was premixed with fouling bacteria strain $\left(1 \times 10^{8}\right.$ cells ml$\left.^{-1}\right)$. Plates were incubated at $35{ }^{\circ} \mathrm{C}$ for $24-48 \mathrm{~h}$. Antagonistic activity was determined by the formation of a clear inhibition zone around each strain. The assay was carried out in triplicate. Copper oxide was used as control.

On the basis of these results, the most active bacteria (potential antifoulants) were 
TABLE 1

Sample origin and isolation method

\begin{tabular}{lll}
\multicolumn{1}{c}{ Sample } & \multicolumn{1}{c}{ Collection site } & \multicolumn{1}{c}{ Isolation } \\
$\begin{array}{l}\text { Rhizophora mangle soil } \\
\text { Rhizophora mangle root, leaf, seaweed } \\
\text { (Ulva lactuca) }\end{array}$ & $\begin{array}{l}\text { "Conchalito" Mangrove, B.C.S. } \\
\text { "Conchalito" Mangrove, B.C.S. }\end{array}$ & $\begin{array}{l}\text { g in saline solution } \\
\text { Seahorse (Hippocampus in tubes with sterile seawater }\end{array}$ \\
$\begin{array}{l}\text { Sponge } \\
\text { (Aplysina gerardogreeni) }\end{array}$ & $\begin{array}{l}\text { "Coromuel" and "La Bruja" beach, } \\
\text { B.C.S. }\end{array}$ & Swab in tubes with sterile seawater \\
& Punta Arena, B.C.S. & $\begin{array}{l}1 \mathrm{~g} \text { in sterile water, ground using } \\
\text { mortar and transferred into sterile }\end{array}$ \\
\hline
\end{tabular}

Seahorse authorization of scientific collection SGPA/DGVS/08366/12

selected and bioactivity was confirmed by secondary screening through the agar well diffusion method with supernatant. Thirty-one antagonist isolates were selected and grown individually in $500 \mu \mathrm{l}$ of Marine Broth, incubated for $48 \mathrm{~h}$ at $35{ }^{\circ} \mathrm{C}$. Culture broths were centrifuged at $15000 \mathrm{rpm}$ for $10 \mathrm{~min}$ at $4{ }^{\circ} \mathrm{C}$ and the supernatant obtained was individually tested for potential growth-inhibition activity against six fouling bacterial strains. Overnight cultures of fouling bacterial strains at $1 \times 10^{8}$ cell $\mathrm{ml}^{-1}$ were spread over MA plates using sterile cotton swabs. Wells $(6 \mathrm{~mm})$ were drilled over MA plates and filled with $40 \mu \mathrm{l}$ of culture supernatant. Plates were incubated at $35{ }^{\circ} \mathrm{C}$ for $24 \mathrm{~h}$ and the inhibition zone $(\mathrm{mm})$ formed around each well was measured and recorded. The assay was carried out in triplicate. Copper oxide was used as control.

Bacterial identification: The strong-fouling bacterial strains and bacteria that showed the highest antimicrobial activity were identified by partial sequencing of $16 \mathrm{~S}$ rRNA gene fragments. DNA was obtained using a commercial kit (UltraClean ${ }^{\circledR}$ Microbial DNA Isolation Kit, MoBio, Laboratories Inc.). Oligonucleotide primers (Forward 27f 5'-GAGTTTGATCCTGGCTCA- 3' and Reverse 1385R 5' - CGGTGTGTRCAAGGCCC-3') were used to amplify the $16 \mathrm{~S}$ rRNA gene fragments. A single PCR cycle consisted of initial denaturation at $95{ }^{\circ} \mathrm{C}$ for $2 \mathrm{~min}$ and 30 cycles of 95 ${ }^{\circ} \mathrm{C}$ for $60 \mathrm{~s}$, annealing at $55{ }^{\circ} \mathrm{C}$ for $60 \mathrm{~s}, 72{ }^{\circ} \mathrm{C}$ for $70 \mathrm{~s}$, and extension at $72{ }^{\circ} \mathrm{C}$ for $10 \mathrm{~min}$. PCR amplicons were purified and DNA was sequenced by MACROGEN in Korea. Searches of the Genbank database were performed using the BLAST program at the National Center for Biotechnology Information website (http://www.ncbi.nlm.nih.gov), sequence data were compared to sequences of the closest relatives according to BLAST searches.

Crude extracts preparation: Strains were grown in $250 \mathrm{ml}$ of Marine Broth and incubated on a rotary shaker at $150 \mathrm{rpm}$ for 72 $\mathrm{h}$ at $35^{\circ} \mathrm{C}$. The fermentation broth was extracted using Diaion HP-20 (Sigma-Aldrich) resin. The adsorbent resin was soaked and swelled in $100 \%$ methanol for $12 \mathrm{~h}$ to remove impurities, solvent was completely removed by rinsing with distilled water (Rakesh et al., 2011). Wet resin was weighed at $5 \%$ level and added to the fermented broth. This mix was agitated on a shaker for $12 \mathrm{~h}$ at $150 \mathrm{rpm}$. The fermented broth with adsorbent resin was filtered and the supernatant discarded. Two-hundred milliliters of methanol were added to the pellet containing Diadion HP-20 and cell mass, this was agitated on a shaker for $1 \mathrm{~h}$ at $150 \mathrm{rpm}$, and metabolites were extracted. The pellet was re-extracted with ethyl acetate following the same procedure. The methanol and ethyl acetate fractions were aggregated and concentrated in vacuum by rotary evaporator at $38{ }^{\circ} \mathrm{C}$ and $200 \mathrm{rpm}$. The crude extract obtained was dissolved in the minimum amount of methanol, collected in 
pre-weighed vials and evaporated to dryness. Weight of the crude extract was estimated and stored at $4{ }^{\circ} \mathrm{C}$ (Pinzón Espinosa, 2012).

Antimicrofouling activities: The antibacterial assay was performed using crude extract against fouling bacterial strains. Minimum inhibitory concentration (MIC) was determined following the method described by Hellio, Trepos, Aguila-Ramírez and Hernández-Guerrero (2015). Stock solutions of bacterial extracts were prepared in methanol (as a carrier solvent) with final concentrations of $0.01,0.1$, 1,10 and $50 \mu \mathrm{g} \mathrm{ml}^{-1}$. An aliquot $(100 \mu \mathrm{l})$ of these solutions was pipetted into 96-well plates and methanol evaporated for $24 \mathrm{~h}$. Qualitative assays for each concentration were performed with six replicates.

The bacterial cultures were diluted according to the Amsterdam method (Amsterdam, 1996) to a cell density of $2 \times 10^{8}$ cells $\mathrm{ml}^{-1}$. Microplates coated with extracts were inoculated with $100 \mu \mathrm{l}$ bacterial cell suspension and incubated at $35^{\circ} \mathrm{C}$ for $48 \mathrm{~h}$. The bacterial extracts were considered active if four out of six wells showed inhibition. Culture medium with extract lacking inoculated bacteria was used as blank, copper oxide as positive control and methanol as a negative control (Chambers et al., 2011). After incubation, all the wells were visually compared to the control; clear wells indicated growth inhibition.

The antimicroalgal bioassay was performed using five widely distributed microphytobenthic strains that constitute fouling model species, these were provided by AlgobankCaen: Cylindrotheca closterium AC170, Exanthemachrysis gayraliae AC15, Halamphora coffeaeformis AC713, Pleurochrysis roscoffensis AC32, Porphyridium purpureum AC122.

Strains were cultivated using $\mathrm{f} / 2$ media (Guillard \& Ryther, 1962) and maintained at $20{ }^{\circ} \mathrm{C}$ and constant light (incident irradiance: $\left.140 \mu \mathrm{mol} \mathrm{m} \mathrm{m}^{-2} \mathrm{~s}^{-1}\right)$. Biomass was estimated from Chlorophyll $a(\mathrm{Chl} a)$ concentration measurements following the method described by Id Daoud (2015). Five milliliters of microalgal culture were collected with GF/F filter
(Whatman) and immediately transferred to a vial containing $5 \mathrm{ml}$ of analytical grade methanol. The vial was kept under the absence of light at $4{ }^{\circ} \mathrm{C}$ from $30 \mathrm{~min}$ to $2 \mathrm{~h}$. Fluorescence of the pigment extract was measured (PolarSTAR Optima BMG Labtech; excitation: 485 $\mathrm{nm}$, emission: $645 \mathrm{~nm}$ ) and Chl $a$ concentration was determined with a calibration curve constructed using spinach Chl $a$ (C5753 Sigma, extinction coefficient at $663 \mathrm{~nm}$ in methanol: 77 $\mathrm{lg}^{-1} \mathrm{~cm}^{-1}$ ) solutions contained in the GF/F filter that had been previously used for seawater filtering. Dilutions were made for each species to obtain aliquots of microalgal suspension with a starting concentration of $0.1 \mathrm{mg} \mathrm{Chl} a \mathrm{l}^{-1}, 100$ $\mu 1$ were added to each well of the microplates previously coated under aseptic conditions. Inoculated microplates were incubated for $5 \mathrm{~d}$ at $20{ }^{\circ} \mathrm{C}$ under constant light (incident irradiance: $140 \mu \mathrm{mol} \mathrm{m} \mathrm{m}^{-2} \mathrm{~s}^{-1}$ ), each well was visually compared to the controls; clear wells indicated growth inhibition (Chambers et al., 2011).

\section{RESULTS}

In this research, native marine bacteria were collected in the Gulf of California, these presented antimicrofouling activity against bacteria and microalgae.

Biofilm sample collection: According to the adhesion test, ten bacteria formed biofilm, six of these strains were isolated from silicon coatings and four from copper-free coatings. No bacteria were isolated from the panel with copper. The strains were closest to the genus Bacillus (Table 2). Three strains of each coating developed strong biofilm in the wells, these were selected for antagonism test.

Isolation of associated bacteria: A total of 125 bacterial colonies were isolated and purified, 94 were isolated from mangrove and Ulva lactuca Linnaeus, 1753, three from the sponge Aplysina gerardogreeni Gómez \& Bakus, 1992 and 28 from the seahorse Hippocampus ingens Girard, 1858. The origin of each strain is shown in Table 3. 
TABLE 2

Biofilm strain sample collection

\begin{tabular}{clccc} 
Isolate & \multicolumn{1}{c}{ Closely-related species } & Access number GenBank & \% Identity & Coating \\
5-ADH* & Bacillus altitudinis IHBB15457 & KM817260.1 & 99 & CF \\
12-ADH & Bacillus subtilis G47 & AB999979.1 & 100 & $\mathrm{~S}$ \\
13-ADH* & Bacillus altitudinis IHBB15457 & KM817260.1 & 99 & $\mathrm{~S}$ \\
14-ADH & Bacillus subtilis 141-1 & AB999955.1 & 100 & $\mathrm{~S}$ \\
17-ADH & Bacillus subtilis 141-1 & AB999955.1 & 99 & $\mathrm{CF}$ \\
18-ADH & Bacillus altitudinis 2-5J-2-2-4M & KJ009482.1 & 97 & $\mathrm{CF}$ \\
25-ADH* & Micrococcus flavus HME8781 & KC134360.2 & 99 & $\mathrm{CF}$ \\
27-ADH* & Bacillus pumilis VB6 & JN215511.1 & 99 & $\mathrm{~S}$ \\
30-ADH* & Bacillus subtilis 1921-1 & AB999979.1 & 98 & $\mathrm{~S}$ \\
31-ADH* & Bacillus cereus BDUS & JX847620.1 & 98 & $\mathrm{CF}$ \\
\hline
\end{tabular}

*Strong biofilm producers used in bioassays, CF Copper-free, S Silicon.

TABLE 3

Marine-bacterial isolates and biofilm-producing bacteria considered for screening

\begin{tabular}{|c|c|c|c|c|c|c|c|}
\hline \multirow{2}{*}{ Isolate } & \multirow{2}{*}{ Source } & \multicolumn{6}{|c|}{ Biofilm-producing bacteria } \\
\hline & & $5 \mathrm{ADH}$ & $13 \mathrm{ADH}$ & $25 \mathrm{ADH}$ & $27 \mathrm{ADH}$ & $30 \mathrm{ADH}$ & $31 \mathrm{ADH}$ \\
\hline 1 & Ulva lactuca & - & $* * *$ & $* * *$ & $* * *$ & - & - \\
\hline 2 & Ulva lactuca & - & $* *$ & $* * *$ & $* *$ & - & - \\
\hline 3 & Ulva lactuca & - & - & - & $*$ & - & - \\
\hline 4 & Ulva lactuca & - & - & - & $*$ & - & - \\
\hline 5 & Ulva lactuca & - & - & - & $*$ & - & - \\
\hline 17 & Hippocampus ingens & - & - & - & - & - & - \\
\hline $17-2$ & Hippocampus ingens & - & - & - & - & - & - \\
\hline 18 & Hippocampus ingens & - & $* * * *$ & - & $* * * *$ & $* * * *$ & - \\
\hline 19 & Rhizophora mangle leaf & - & - & - & - & - & - \\
\hline 22 & Rhizosphera soil & - & $*$ & $*$ & - & - & - \\
\hline 25 & Rhizophora mangle leaf & - & $*$ & - & $* *$ & - & - \\
\hline 26 & Rhizophora mangle leaf & - & $*$ & - & $*$ & - & - \\
\hline 27 & Rhizophora mangle leaf & - & $*$ & - & $*$ & - & - \\
\hline 28 & Rhizophora mangle leaf & $* * *$ & $* * *$ & $* *$ & $* * *$ & $* * * *$ & - \\
\hline 32 & Rhizophora mangle root & - & $*$ & - & $*$ & - & - \\
\hline 33 & Rhizophora mangle root & - & $* *$ & - & $* *$ & $* *$ & - \\
\hline 37 & Rhizophora mangle root & - & $* *$ & - & $* *$ & $* *$ & - \\
\hline 38 & Aplysina gerardogreeni & - & $* *$ & - & $* *$ & $* *$ & - \\
\hline 39 & Aplysina gerardogreeni & - & $* *$ & - & $*$ & $* *$ & - \\
\hline 40 & Aplysina gerardogreeni & - & $* *$ & - & $* *$ & $* *$ & - \\
\hline 45 & Ulva lactuca & - & $*$ & $*$ & - & $*$ & - \\
\hline 73 & Rhizophora mangle root & $*$ & - & - & - & - & - \\
\hline 78 & Rhizophora mangle root & - & $* * * *$ & - & $* *$ & $* *$ & - \\
\hline 88 & Rhizophora mangle root & - & $* * *$ & $* * *$ & $* *$ & $* * *$ & $*$ \\
\hline 94 & Hippocampus ingens & - & $* *$ & $* *$ & $* *$ & $* *$ & - \\
\hline 101 & Hippocampus ingens & $* * *$ & - & - & - & - & - \\
\hline 115 & Hippocampus ingens & - & $* *$ & $* *$ & $* *$ & $* *$ & - \\
\hline 116 & Hippocampus ingens & $*$ & - & $*$ & $*$ & - & - \\
\hline
\end{tabular}


TABLE 3 (Continued)

\begin{tabular}{|c|c|c|c|c|c|c|c|}
\hline \multirow{2}{*}{ Isolate } & \multirow{2}{*}{ Source } & \multicolumn{6}{|c|}{ Biofilm-producing bacteria } \\
\hline & & $5 \mathrm{ADH}$ & $13 \mathrm{ADH}$ & $25 \mathrm{ADH}$ & $27 \mathrm{ADH}$ & $30 \mathrm{ADH}$ & $31 \mathrm{ADH}$ \\
\hline 117 & Hippocampus ingens & - & $* *$ & $* *$ & $* *$ & $* *$ & - \\
\hline 121 & Rhizophora mangle root & $* * *$ & $* * *$ & $* *$ & $* *$ & $* * * *$ & - \\
\hline 122 & Rhizophora mangle root & $*$ & $*$ & $*$ & $*$ & $*$ & - \\
\hline Control + & Copper oxide & $* * * *$ & $* * * *$ & $* * * *$ & $* * * *$ & $* * * *$ & $* * * *$ \\
\hline
\end{tabular}

Halos (mm): * (05-10mm), ** (11-15mm), *** (16-20mm), **** (21-25mm), -(inactive).

Screening of marine bacteria isolate: Thirty-one associated isolates were active and showed inhibition halos around each strain on the primary screening against fouling bacterial strains. These were considered candidates for secondary screening. Table 3 shows that from these bacteria, 16 strains presented potential inhibitory activity with halos greater than 10 $\mathrm{mm}$, where most of them exhibited inhibitory activity against at least three of the biofilmforming bacteria. Some strains, such as 28,88 and 121 presented inhibitory activity against five biofilm bacteria strains with halos between 11 and $20 \mathrm{~mm}$. The highest activity was found in strain 18 , which was similar to that of the control, showing inhibition halos of 21 to 25 $\mathrm{mm}$ against three biofilm-forming bacteria (13-ADH, 27-ADH and 30-ADH); these biofilm bacteria were inhibited by $42 \%$ of the bacterial strains.

Antimicrofouling activities: Organic extracts of the 16 active strains were obtained for a third screening. Average extract yield was $2.4 \mathrm{~g} \mathrm{l}^{-1}$, extract 94 showed the highest yield with $3.4 \mathrm{~g} \mathrm{l}^{-1}$ and extract 1 the lowest $\left(1.9 \mathrm{~g} \mathrm{l}^{-1}\right)$. Extracts were tested against biofilm-forming bacteria, which were mostly inhibited in the previous assays (3). Ten extracts were active against at least one biofilm-forming strain, most at the lowest concentration tested (Table 4). The strongest antibacterial activity was found

TABLE 4

Minimal Inhibitory Concentration (MIC) of marine-bacterial extracts against biofilm-producing bacteria $\left(\mu \mathrm{g} \mathrm{ml}^{-1}\right)$

\begin{tabular}{|c|c|c|c|}
\hline \multirow{2}{*}{ Extract } & \multicolumn{3}{|c|}{ Biofilm-producing bacteria } \\
\hline & Bacillus altitudinis (13 ADH) & Bacillus pumilus (27 ADH) & Bacillus subtilis (30 ADH) \\
\hline 1 & 0.01 & 0.1 & - \\
\hline 2 & - & 50 & - \\
\hline 18 & 0.1 & 0.01 & 0.01 \\
\hline 28 & 0.01 & 0.01 & - \\
\hline 33 & - & - & - \\
\hline 37 & - & - & - \\
\hline 38 & 0.01 & 0.1 & - \\
\hline 39 & - & 50 & - \\
\hline 40 & - & 0.01 & 50 \\
\hline \multicolumn{4}{|l|}{78} \\
\hline 88 & 0.01 & 0.01 & - \\
\hline 94 & - & 0.1 & 0.1 \\
\hline 101 & - & - & - \\
\hline 115 & - & - & - \\
\hline 117 & - & - & - \\
\hline 121 & 0.01 & - & - \\
\hline Control + & 0.01 & 0.01 & 0.01 \\
\hline
\end{tabular}


in extract 18, which showed wide spectrum of growth inhibition on fouling bacterial strains.

All the extracts exhibited antimicroalgal activity at the maximum concentration tested $\left(50 \mu \mathrm{g} \mathrm{ml}^{-1}\right)$. Only five were active at low concentrations (Table 5), in concordance with the extract that presented antibacterial activity.

Bacterial identification: The ten isolates that showed the best activity against microorganisms (bacteria and microalgae) were identified; five of them belong to the genus Bacillus.
The two strains that showed the highest activity correspond to Shewanella algae (18) and Staphylococcus sp. (28). The first was isolated from the seahorse Hippocampus ingens, while the latter was isolated from the mangrove Rhizophora mangle. Table 6 presents BLAST (NCBI) results.

\section{DISCUSSION}

In this study, the antimicrofouling activity against colonizing bacteria and microalgae

TABLE 5

Minimal Inhibitory Concentration (MIC) of marine-bacterial extracts against microalgae $\left(\mu \mathrm{g} \mathrm{ml}^{-1}\right)$

\begin{tabular}{cccccc} 
Extract & $\begin{array}{c}\text { Cylindrotheca } \\
\text { closterium }\end{array}$ & $\begin{array}{c}\text { Exanthemachrysis } \\
\text { gayraliae }\end{array}$ & $\begin{array}{c}\text { Halamphora } \\
\text { coffeaeformis }\end{array}$ & $\begin{array}{c}\text { Pleurochrysis } \\
\text { roscoffensis }\end{array}$ & $\begin{array}{c}\text { Porphyridium } \\
\text { purpureum }\end{array}$ \\
$\mathbf{1}$ & 10 & 10 & 0.1 & 0.1 & 1 \\
$\mathbf{2}$ & 1 & 1 & 1 & 1 & 1 \\
18 & 0.1 & 0.1 & 1 & 0.1 & 0.1 \\
28 & 0.1 & 0.1 & 0.01 & 0.1 & -1 \\
33 & 50 & 50 & - & 50 & 50 \\
37 & 50 & 50 & 50 & 50 & 1 \\
$\mathbf{3 8}$ & 1 & 0.1 & 1 & 1 & 50 \\
39 & 50 & 50 & 50 & 50 & 50 \\
40 & 50 & 50 & 50 & 50 & 50 \\
78 & 50 & 50 & 50 & 50 \\
88 & 50 & 50 & 50 & 50 & 50 \\
94 & 50 & 50 & 50 & 50 & - \\
101 & - & 50 & 10 & 50 & 50 \\
115 & 50 & 50 & 50 & 1 & 50 \\
117 & 50 & 50 & 10 & 50 & 50 \\
121 & 50 & 50 & 50 & 0.1 & 0.1 \\
\hline
\end{tabular}

TABLE 6

Bacterial strains with antifouling potential and closely related species from GenBank according to 16S RNA gene

\begin{tabular}{|c|c|c|c|c|}
\hline Isolate & Source & Closely related species & Access number GenBank & $\%$ Identity \\
\hline 1 & Ulva lactuca & Bacillus licheniformis & KF963618.1 & 99 \\
\hline 2 & Aplysina gerardogreeni & Bacillus safensis & KX277964.1 & 100 \\
\hline 18 & Hippocampus ingens & Shewanella algae & KX272636.1 & 98 \\
\hline 28 & Rhizophora mangle leaf & Staphylococcus sp. & LT545683.1 & 99 \\
\hline 38 & Aplysina gerardogreeni & Bacillus subtilis & JF501099.1 & 98 \\
\hline 39 & Aplysina gerardogreeni & Bacillus pumilus & JX102495.1 & 100 \\
\hline 40 & Aplysina gerardogreeni & Bacillus licheniformis & JX164088.1 & 99 \\
\hline 88 & Rhizophora mangle root & Pseudoalteromonas ruthenica & FJ457211.1 & 99 \\
\hline 94 & Hippocampus ingens & Marinobacter sp. & EF587996.1 & 95 \\
\hline 121 & Hippocampus ingens & Staphylococcus warneri & KT868882.1 & 100 \\
\hline
\end{tabular}


was assessed for marine bacteria collected in the Gulf of California. Biofouling prevention, control, and damage repair constitute one of the most significant expenses for the shipping, port and aquaculture industries (Armstrong, Boyd, $\&$ Burgess, 2000). Common paintings have a limited application given that their effectiveness is reduced due to the wide diversity of microbiological communities from different water bodies of the world. The vast majority of antifouling solutions available in the market claim to have broad-spectrum activity; this is the best offer for cargo ships that have to cross different areas of the world's oceans, thus the hulls of these ships are exposed to different fouling communities. On the other hand, most recreational, fishing and ferry boats operate in small areas and have very specific coating requirements that are particular to the species thriving in the area. In coasts with large numbers of man-made structures, such as $\mathrm{La}$ Paz bay, one antifouling strategy is to develop novel efficient and non-toxic regional coatings that are active against local species.

We decided to identify cultivable fouling bacteria that typically colonize coatings in La Paz Bay, Gulf of California in order to develop a coating that targeted on fouling species, enabling its application on resident boats and immersed man-made structures such as pontoons, aquaculture devices and buoys. The high degree of adhesion capacity of the bacteria isolated from panels coated with antifouling paint (provided by a company specialized in the field) was evidenced within the first hours of immersion under water in a site located southwest of the bay. Therefore, according to previous studies, these bacteria may be considered as precursor organisms for the process of biofouling (Hellio et al., 2005).

The search for paints with less toxic antifouling agents that reduce or inhibit the colonization of algae or invertebrates in submerged man-made structures is an emergent subject (IMO, 2003). Coatings currently used in marine industries are copper-based, it has been documented that this type of coating affects directly invertebrates and indirectly the microbial biolayer that is formed prior to the settlement process, delaying the formation of such biolayer but not inhibiting the whole ensemble (McElroy et al., 2017). This was evidenced in the present study, given that the antifouling paint (coating the metal tubes) was copper-based and no bacteria were isolated after exposure period.

Biofilm-forming microorganisms have the ability to modify settlement surfaces, making them rougher, which reduces significantly the activity and efficacy of antifouling paints (Cassé \& Swain, 2006). The adherent bacteria and precursors of the biofouling process isolated in La Paz bay were Gram positive, the genus Bacillus was the best represented in most of the bacteria according to the high percentage of identity similarity with regard to the species reported in Genbank.

Adherent bacteria, such as Bacillus and Pseudomonas, have shown to provide the substrate for larger fouling organisms by forming an exopolymer biofilm (Bhosale, Nagle, \& Jagtap, 2002). The chemical composition of this type of biofilm depends on microbialcell genetics and the physical-chemical environment in which the extracellular matrix is developed (Sutherland, 2001). These bacteria are known for using surface proteins (AtlE, Bap, Esp) during the first adhesion stage (Cucarella et al., 2001; Toledo-Arana et al., 2001; Lasa, 2004). In addition, these microorganisms are particularly resistant to most antimicrobial agents (Olson, Ceri, Morck, Buret, \& Read, 2002) due to the excretion of exopolymeric substances, which gives them the ability to survive on antifouling surfaces (Costerton, Lewandowski, Caldwell, Korber, \& Lappin-Scott, 1995). Therefore, these bacteria are key targets for the development of new antifouling solutions.

The Gulf of California is classified as world heritage location by UNESCO. It harbors a very rich marine biodiversity and it is recognized as an area of global marine conservation significance. The striking productivity of the Gulf of California is majorly due to the presence of nutrient-rich upwelling oceanic 
currents that support abundant phytoplankton and zooplankton, which in turn provide nurseries for reef-fish larvae. Almost 900 species of fish have been documented in the Gulf, with around 90 endemic species. This marine habitat also shelters large concentrations of macroinvertebrate life with many endemic species, especially at intertidal zones. The greatest impacts on marine biodiversity are caused by fishing (artisanal, industrial and sport) and pollution (agriculture, industry and sewage) (UNESCO, 2017). In the marine environment, one way to reduce pollution inputs is to enforce the use of non-toxic antifouling paints in protected areas. Thus, this study had the purpose of finding marine microorganisms that secrete inhibitory substances to bacterial adhesion, avoiding biofouling on man-made structures in La Paz bay.

Maréchal and Hellio (2011) demonstrated that compounds specific to a given ecological context can potentially improve their efficacy over targeted species: compounds located at the surface of algae and/or microbiota play a role in chemical communication among species and in defense against epibiosis. Moreover, opportunities to find new compounds with targeting activity increase when sampling and experimentation is made within local environments, while chances of finding compounds with a broad range of activity is higher when focusing on foreign species or species with wide distribution ranges. These considerations influence species selection to be screened in the search for antifouling activity (AF) and bioassays. In this regard, in order to design specific antifouling formulations for man-made structures in the Gulf of California, sampling of organisms that produce bioactive-natural products must be carried out in this same area.

In this study, several organisms and marine substrates were selected for anti-fouling assessment. Some of these bacteria, such as those associated with sponges, seahorses and seaweeds, protect their hosts by emitting inhibitory compounds, thus preventing the colonization of microorganisms and the adhesion of other organisms (Marhaeni et al., 2011; Supardy, Ibrahim, Nor, \& Md, 2017).

A number of studies have focused on antifouling activities of marine organisms such as macroalgae and sponges (Vimala, 2016). However, these are usually limited due to contingencies on their experimental designs, which include different seasons, not reaching minimum volumes for extraction (Mendola, 2003; 2006), and compounds with complex molecular structures that cannot be chemically synthesized (Vimala, 2016). However, León, Liza, Soto, Torres, and Orozco (2010), and Kelecom (2002) noted that microorganisms are fast-growing species that can be produced via fermentation. Marine microorganisms are suitable candidates for bioactive-compound production, which inhibit the settlement of micro and macrofouling (Vimala, 2016).

The mangrove ecosystem is a particular environment harboring diverse groups of microorganisms that play key roles in nutrient transformation (Thatoi et al., 2013). Degradation of mangrove plant material begins with the colonization of fungi and bacteria (Grossart et al., 2003). These bacteria produce numerous metabolic substances with a wide range of biological activity, such as enzyme production, phosphate solubilization, hydrocarbon utilization, plant growth hormone production, nitrogen fixation and microbial activities (Sahoo \& Dahl, 2009). Within a community, this is considered a selective force, a competition for resources that promotes the biosynthesis of antimicrobial compounds (Slattery et al., 2001). In concordance, a number of bacteria collected in the mangrove ecosystem in this study presented activity.

Furthermore, primary screening showed antagonistic interactions between epiphytic bacteria and fouling bacteria. Some of these bacteria are able to excrete various secondary metabolites that lead to a broad-spectrum antibacterial activity, while others produce narrow spectrum, specific metabolites that are active against a selected group of biofilm bacteria. To select the bacteria with the highest antifouling potential, those displaying the broadest 
spectrum of inhibitory activity against the highest number of biofilm-forming bacteria tested were selected. These biofilm-forming bacteria, when isolated from antifouling coatings, indicate a challenge for their inhibition as they were adhered to a substrate which already contained a commercial biocide and thus could be defined as resistant to actual paint formulation.

In the biofouling process, the initial attachment of fouling bacteria on the submerged surface is followed by the development of a biofilm harboring a complex biodiversity of bacteria and microalgae. Therefore, the results of this study suggest that extracts of bacteria can possess not only antibacterial property against the fouling bacteria but can also prevent the settlement of microalgae.

In this study, the bacteria with the best antifouling activity corresponded to Shewanella algae (18) and Staphylococcus sp. (28). The first was isolated from the seahorse (Hippocampus ingens), while the second was isolated from the mangrove (Rhizophora mangle). Shewanella spp. biofilms have been found to modulate the settlement (with inductive or inhibitory effects) of a variety of macroscopic algae and invertebrates such as Ulva spores, cypris, mussel larvae, or sea urchin larvae (Martín-Rodríguez et al., 2014). Hare et al. (2005) described an algicidal bacterium, Shewanella sp. IRI-160, isolated from the Delaware River, USA, with a negative effect on the growth of three dinoflagellates (Pfiesteria piscicida, Prorocentrum minimum and Gyrodinium uncatenum). Also, Rachanamol, Lipton, Thankamani, Sarika and Selvin (2014) found that the strain of Shewanella algae associated with the sponge Callyspongia difussa had biological activity against bacteria and fungi.

Staphylococcus is a well known genus for its human and animal infections, but some species have been recognized as common commensals (Mani et al., 2016). Recent studies have reported that some secondary metabolites produced by Staphylococcus species isolated from natural environments exhibited biotechnological and biomedical significance (Popowicz et al., 2006). Zhang, Jiang, Jiang and
Huang (2016) reported antimicrobial activity for cell-free supernatants of $S$. epidermidis isolated from the internal organs of a marine organism against human pathogens. Vandecandelaere, Depuydt, Nelis, and Coenye (2014) reported the $S$. epidermidis produced protease with effects on $S$. aureus biofilms and Mani et al. (2016) report a marine Staphylococcus saprophyticus SBPS 15, identified as a promising biosurfactant producer with antimicrobial activity against many humans pathogenic bacterial and fungal.

According to the literature review, no studies have been reported on Staphylococcus for antifouling activity. It is possible that it is the first report of this activity attributed at the extract of marine Staphylococcus strain. However, some antifouling coatings based on natural products of marine organisms such as Sea-Nine ${ }^{\mathrm{TM}}$ 211, Netsafe ${ }^{\mathrm{TM}}$ and Pearlsafe ${ }^{\mathrm{TM}}$ have been commercialized, as they have been reported to be highly effective against the first phase of the biofilm formed by bacteria and diatoms. The last two are derivatives produced by red algae (Delisea pulchra), while the active molecule of Sea-Nine ${ }^{\mathrm{TM}} 211$ is isothiazolon, which is produced by soft coral of the genus Eunicea (Jacobson \& Willingham, 2000).

The results obtained in this study provide guidelines for continuing investigations using these extracts to prove their effectiveness in the field and evaluate its toxicity, in the future they could be incorporated in coatings formulations to evaluate their activity in the marine environment. Developing a natural product antifouling coatings based on microbes takes much time and efforts. The toxicity of compounds produced by these microbes on non-target organisms in the marine ecosystem also needs to be analyzed before commercial applications (Dobretsov, Abed, \& Teplitski, 2013).

Ethical statement: authors declare that they all agree with this publication and made significant contributions; that there is no conflict of interest of any kind; and that we followed all pertinent ethical and legal 
procedures and requirements. A signed document has been filed in the journal archives.

\section{ACKNOWLEDGMENTS}

Authors thank Comex Industrial Coatings S.A. of C.V. for providing the steel panels. This work was supported by CONACYT under Grant 210637 "Development of a technological platform of antifouling coatings of low environmental impact" of Comex Industrial Coatings S.A. of C.V.

\section{RESUMEN}

Bacterias marinas del Golfo de California con actividad antimicrobiana frente a bacterias colonizadoras y microalgas. Una alternativa para reducir la contaminación en el medio marino es el uso de pinturas anti-incrustantes no tóxicas en áreas marinas protegidas. En el presente estudio se propuso encontrar microorganismos marinos que secreten sustancias capaces de inhibir la adhesión de bacterias y microalgas, de esta manera evitar la bioincrustación en estructuras marinas en la bahía de La Paz, B.C.S., México. Un total de 125 bacterias fueron evaluadas por su capacidad para inhibir el desarrollo de bacterias formadoras de biopelículas. En una selección preliminar de actividad antagónica y antibacteriana, 16 cepas bacterianas mostraron potencial actividad inhibitoria, de las que se obtuvieron los extractos crudos con metanol y acetato de etilo. Se realizaron ensayos antibacterianos y anti-microalgales utilizando los extractos crudos, se determinó la concentración mínima inhibitoria (MIC). Dos cepas mostraron la mayor actividad contra bacterias y microalgas: Shewanella algae y Staphylococcus sp. Los resultados de este estudio sugieren que los extractos de bacterias aisladas en el Golfo de California que poseen propiedades antimicrobianas contra las bacterias formadoras de biofilm y también pueden prevenir la adhesión de microalgas, con lo que se podría controlar el desarrollo de la formación de biopelículas y como consecuencia, el biofouling.

Palabras clave: epibiontes; extractos; Shewanella; Staphylococcus; contaminación biológica; anti-incrsutante.

\section{REFERENCES}

Alzieu, C. (2000). Impact of tributyltin on marine invertebrates. Ecotoxicology, 9, 71-76. DOI: 10.1023/A:1008968229409

Amsterdam, D. (1996). Susceptibility testing of antimicrobials in liquid media. In V. Loman (Ed.), Antibiotics in laboratory medicine (pp. 52-111). Baltimore Md, USA: Williams \& Wilkins.

Armstrong, E., Boyd, K. G., \& Burgess, J. G. (2000). Prevention of marine biofouling using natural compounds from marine organisms. Biotechnology Annual Review, 6, 221-241. DOI: 10.1016/ S1387-2656(00)06024-5

Balcázar, J. L., Loureiro, S., Da Silva, Y. J., Pintado, J., \& Planas, M. (2010). Identification and characterization of bacteria with antibacterial activities isolated from seahorses (Hippocampus guttulatus). Journal of Antibiotics, 63, 271. DOI: https://doi.org/10.1038/ ja. 2010.27

Bernbom, Ng. Y. Y, Kjelleberg, S., Harder, T., \& Gram, L. (2011). Marine bacteria from Danish coastal waters show antifouling activity against the marine fouling bacterium Pseudoalteromonas sp. Strain S91 and Zoospores of the Green Alga Ulva australis independent of bacteriocidal activity. Applied and Environmental Microbiology, 77, 8557-8567. DOI: 10.1128/ AEM.06038-11

Bhosale, S. H., Nagle, V. L., \& Jagtap, T. G. (2002). Antifouling potential of some marine organisms from India against species of Bacillus and Pseudomonas. Marine Biotechnology, 4, 111-118. DOI: 10.1007/ s10126-001-0087-1

Cassé, F., \& Swain, G. W. (2006). The development of microfouling on four commercial antifouling coatings under static and dynamic immersion. International Biodeterioration and Biodegradation, 57, 179-185. DOI: 10.1016/j.ibiod.2006.02.008

Callow, J. A., \& Callow, M. E. (2011). Trends in the development of environmentally friendly fouling-resistant marine coatings. Nature communications, 2, 244. DOI: https://doi.org/10.1038/ncomms1251

Chambers, L. D., Hellio, C., Stokes, K. R., Dennington, S. P., Goodes, L. R., Wood, R. J. K., \& Walsh, F. C. (2011). Investigation of Chondrus crispus as a potential source of new antifouling agents. International Biodeterioration and Biodegradation, 65, 939-946. DOI: https://doi.org/10.1016/j.ibiod.2011.07.002

Costerton, J. W., Lewandowski, Z., Caldwell, D. E., Korber, D. R., \& Lappin-Scott, H. M. (1995). Microbial biofilms. Annual Review Microbiology, 49, 711-745. DOI: https://doi.org/10.1146/annurev. mi.49.100195.003431

Ciriminna, R., Bright, F. V., \& Pagliaro, M. (2015). Ecofriendly antifouling marine coatings. ACS Sustainable Chemistry \& Engineering, 3, 559-565. DOI: $10.1021 / \mathrm{sc} 500845 \mathrm{n}$

Cucarella, C., Solano, C., Valle, J., Amorena, B., Lasa, I. I. \& Penades, J. R. (2001). Bap, a Staphylococcus aureus surface protein involved in biofilm formation. 
Journal of Microbiology and Bacteriology, 183, 2888-2896. DOI: 10.1128/JB.183.9.2888-2896.2001

Dobretsov, S., Dahms, H. U., \& Qian, P. Y. (2006). Inhibition of biofouling by marine microorganisms and their metabolites. Biofouling, 22, 43-54. DOI: 10.1080/08927010500504784

Dobretsov, S., Abed, R. M. M., \& Teplitski, M. (2013). Mini-review: Inhibition of biofouling by marine microorganisms. Biofouling, 29, 423-441. DOI: $10.1080 / 08927014.2013 .776042$

Dopazo, C. P., Lemos, M. L., Lodeiros, C., Bolinches, J., Baria J. L., \& Toranzo, A. E. (1988). Inhibitory activity of antibiotic-producing marine bacteria against fish pathogens. Journal of Applied Bacteriology, 65, 97-101. DOI: https://doi. org/10.1111/j.1365-2672.1988.tb01497.x

Egan, S., Harder, T., Burke, C., Steinberg, P., Kjelleberg S., \& Thomas, T. (2013). The seaweed holobiont: understanding seaweed-bacteria interactions. FEMS Microbiology Reviews, 37, 462-476. DOI: 10.1111/1574-6976.12011

El Bour, M., Ismail-Ben Ali, A., \& Ktari, L. (2013). Seaweeds epibionts: Biodiversity and potential bioactivities. In A. Méndez-Vilas (Ed.), Microbial pathogens and strategies for combating them: Science, technology and education (pp. 1298-1306). Badajoz, Spain: Formatex Research Center.

Fusetani, N., \& Clare, A. S. (2006). Preface. In N. Fusetani, \& A. Clare (Ed.), Antifouling Compounds (pp. VIIVIII). Progress in Molecular and Subcellular Biology- Marine Molecular Biology. Berlin, Germany: Springer-Verlag.

Gomes, J., Grunau, A., Lawrence, A. K., Eberl, L., \& Gademann, K. (2013). Bioinspired, releasable quorum sensing modulators. Chemical Communications, 49, 155-157. DOI: $10.1039 / \mathrm{C} 2 \mathrm{CC} 37287 \mathrm{H}$

Guillard, R. R., \& Ryther, J. H. (1962). Studies of marine planktonic diatoms: I. Cyclotella nana Hustedt, and Detonula confervacea (Cleve) Gran. Canadian Journal of Microbiology, 8(2), 229-239.

Grossart, H. P., Kiørboe, T., Tang, K., \& Ploug, H. (2003). Bacterial Colonization of Particles: Growth and Interactions. Applied Environmental Microbiology, 69, 3500-3509. DOI: 10.1128/ AEM.69.6.3500-3509.2003

Hare, C. E., Demir, E., Coyne, K. J., Cary, S. C., Kirchman, D. L., \& Hutchins, D. A. (2005). A bacterium that inhibits the growth of Pfiesteria piscicida and other dinoflagellates. Harmful Algae, 4, 221-234. DOI: https://doi.org/10.1016/j.hal.2004.03.001

Hellio, C., Tsoukatou, M., Maréchal, J. P., Aldred, N., Beaupoli, C., Clare, A. S., ... Roussis, V. (2005). Inhibitory effects of Mediterranean sponge extracts and metabolites on larval settlement of the barnacle Balanus amphirtite. Marine Biotechnology, 7, $297-$ 305. DOI: 10.1007/s10126-004-3150-x

Hellio, C., Trepos, R., Aguila-Ramírez, R. N., \& Hernández-Guerrero, C. J. (2015). Protocol for Assessing antifouling activities of macroalgal extracts. In Natural Products from Marine Algae: Methods and Protocols (pp. 421-435) New York, USA: Humana Press. DOI: 10.1007/978-1-4939-2684-8_27

Hentschel, U., Fieseler, L., Wehrl, M., Gernert, C., Steinert, M., Hacker, J., \& Horn, M. (2003). Microbial diversity of sponges. In W. E. G. Müller (Ed.), Sponges (Porifera) (pp. 59-88). Berlin, Heidelberg: Springer. DOI: $10.1007 / 978-3-642-55519-03$

International Maritime Organization (IMO). (2003). International Convention on the Control of Harmful Anti-fouling System on Ships AFS/CONF/26. Retrieved from https://www.state.gov/documents/organization/208110.pdf

Id Daoud, G. (2015). Investigation of the antifouling properties of extracts from marine microalgae $(\mathrm{PhD}$ Thesis). University of Portsmouth, Portsmouth, U.K.

Jacobson, A., \& Willingham, G. (2000). Sea-nine antifoulant: an environmentally acceptable alternative to organotin antifoulants. The Science of the Total Environment, 258, 103-110. DOI: https://doi.org/10.1016/ S0048-9697(00)00511-8

Kelecom, A. (2002). Secondary metabolites from marine microorganisms. Anais da Academia Brasileira de Ciências, 74, 151-170. DOI: 10.1590/ S0001-37652002000100012

Konstantinou, I. K., \& Albanis, T. A. (2004). Worldwide occurrence and effects of antifouling paint booster biocides in the aquatic environment. a review. Environment International, 30, 235-248. DOI: https://doi. org/10.1016/S0160-4120(03)00176-4

Lasa, I. (2004). Biofilm bacterianos. Instituto de Agrobiotecnologia y Recursos Naturales y Departamento de Producción Agraria, 37, 14-18.

León, J., Liza, L., Soto, I., Torres, M., \& Orozco, A. (2010). Bacterias marinas productoras de compuestos antibacterianos aisladas a partir de invertebrados intermareales. Revista Peruana de Medicina Experimental y Salud Pública, 27, 215-221.

Mani, P., Dineshkumar, G., Jayaseelan, T., Deepalakshmi, K., Kumar, C. G., \& Balan, S. S. (2016). Antimicrobial activities of a promising glycolipid biosurfactant from a novel marine Staphylococcuss aprophyticus SBPS 15. 3 Biotech, 6, 163. DOI: 10.1007/ s13205-016-0478-7

Maréchal, J. P., \& Hellio, C. (2011). Antifouling activity against barnacle cypris larvae: Do target species matter (Amphibalanus amphitrite versus Semibalanus 
balanoides)? International Biodeterioration \& Biodegradation, 65, 92-101. DOI: https://doi.org/10.1016/j. ibiod.2010.10.002

Marhaeni, B., Radjasa, O. K., Khoeri, M. M., Sabdono, A., Bengen, D. G., \& Sudoyo, H. (2011). Antifouling activity of bacterial symbionts of seagrasses against marine biofilm-forming bacteria. Journal of Environmental Protection, 2, 1245. DOI: 10.4236/ jep.2011.29143

Martín-Rodríguez, A. J., González-Orive, A., HernándezCreus, A., Morales, A., Dorta-Guerra, R., Norte, M., \& Fernández, J. J. (2014). On the influence of the culture conditions in bacterial antifouling bioassays and biofilm properties: Shewanella algae, a case study. BMC Microbiology, 14, 102. DOI: 10.1186/1471-2180-14-102

Martínez-Díaz, Y. R. (2010). Evaluación de un bioensayo para medir la inhibición de biopelículas bacterianas como indicativo de la actividad antifoulling de compuestos e origen natural (Tesis de Maestría). Universidad Nacional de Colombia, Bogotá, Colombia.

Martínez-Matamoros, D. (2012). Búsqueda de compuestos bioactivos a partir de bacterias del Phyllum firmicutes aisladas del octocoral Pseudopterogorgia elisabethae recolectado en la isla Providencia (Tesis de Maestría). Universidad Nacional de Colombia, Bogotá, Colombia.

McElroy, D., Hochuli, D., Doblin, M., Murphy, R., Blackburn, R., \& Coleman, R. (2017). Effect of copper on multiple successional stages of a marine fouling assemblage. Biofouling, 1-13. DOI: $10.1080 / 08927014.2017$

Mendola, D. (2003). Aquaculture of three phyla of marine invertebrates to yield bioactive metabolites: process developments and economics. Biomolecular Engineering, 4, 441-458. DOI: https://doi.org/10.1016/ S1389-0344(03)00075-3

Mendola, M. (2006). Agricultural technology adoption and poverty reduction: A propensity -score matching analysis for rural Bangladesh. Food Policy, 32, 372-393. DOI: https://doi.org/10.1016/j. foodpol.2006.07.003

Olson, M. E., Ceri, H., Morck, W. M., Buret, A. G., \& Read, R. R. (2002). Biofilm: formation and comparative susceptibility to antibiotics. Canadian Journal of Veterinary Research, 66, 86-92.

Penesyan, A., Kjelleberg, S., \& Egan, S. (2010). Development of novel drugs from marine surface associated microorganisms. Marine Drugs, 8, 438-459. DOI: 10.3390/md8030438

Pinzón Espinosa, A. C. (2012). Metabolitos mayoritarios y evaluación de actividad antimicrobiana de bacterias aisladas del octocoral Pseudpterogorgia elisabethae del Caribe colombiano (Tesis Doctoral). Universidad Nacional de Colombia, Bogotá, Colombia.

Popowicz, G. M., Dubin, G., Stec-Niemczyk, J., Czarny, A., Dubin, A., Potempa, J., \& Holak, T. A. (2006). Functional and structural characterization of $\mathrm{Spl}$ proteases from Staphylococcus aureus. Journal of Molecular Biology, 358(1), 270-279. DOI: https:// doi.org/10.1016/j.jmb.2006.01.098

Rachanamol, R. S., Lipton, A. P., Thankamani, V., Sarika, A. R., \& Selvin, J. (2014). Molecular characterization and bioactivity profile of the tropical sponge-associated bacterium Shewanella algae VCDB. Helgoland Marine Research, 68, 263-269. DOI: 10.1007/ s10152-014-0386-3

Rakesh, O. D., Pathak, R., Dhaker, A. S., Arora, R., Kumar, R., Rajaram, R., \& Gautam, H. K. (2011). Isolation, characterization and bioactivity of deep sea bacteria with special reference to induction of antibacterial and antioxidant metabolites following gamma irradiation. Canadian Journal of Pure and Applied Science, 5, 1363-1370.

Sahoo, K., \& Dahl, N. K. (2009). Potential microbial diversity in mangrove ecosystems: a review. Indian Journal of Marine Science, 38, 249-256.

Satheesh, S., Ba-akdah, M. A., \& Al-Sofyani, A. (2016). Natural antifouling compound production by microbes associated with marine macroorganisms - A review. Electronic Journal of Biotechnology, 21, 26-35. DOI: https://doi.org/10.1016/j.ejbt.2016.02.002

Slattery, M., Starmer, J., \& Paul, V. (2001). Temporal and spatial variation in defensive metabolites of the tropical Pacific soft corals Sinularia maxima and S. polydactyla. Marine Biology, 138(6), 1183-1193. DOI: $10.1007 / \mathrm{s} 002270100540$

Stepanovic, S., Vukovic, D., Dakic, I., Savic, B., \& Svabic-Vlahovic, M. (2000). A modified microtiterplate test for quantification of staphylococcal biofilm formation. Journal of Microbiological Methods, 40, 175-179.

Supardy, N. A., Ibrahim, D., Nor, S. R. M., \& Md, W. N. (2017). Inhibition of fouling bacteria by the marine epiphytes from selected locations in Malaysia. Malaysian Journal of Science, 36, 17-21. DOI: 10.22452/mjs.vol36no1.2

Sutherland, I. (2001). Biofilm exopolysaccharides: a strong and sticky framework. Microbiology, 147, 3-9. DOI: 10.1099/00221287-147-1-3

Thatoi, H., Behera, B. C., Mishra, R. R., \& Dutta, S. K. (2013). Biodiversity and biotechnological potential of microorganism from mangrove ecosystems, a review. Annals of Microbiology, 63, 1-19. DOI: 10.1007/ s13213-012-0442-7 
Toledo-Arana, A., Valle, J., Solano, C., Arrizubieta, M. J., Cucarella, C., Lamata, M., ... Lasa, I. (2001). The enterococcal surface protein, Esp, is involved in Enterococcus faecalis biofilm formation. Applied Environmental Microbiology, 67, 4538-4545. DOI: 10.1128/AEM.67.10.4538-4545.2001

UNESCO (2017). Islands and Protected Areas of the Gulf of California. Retreived from http://whc.unesco.org/ en/list/1182

Vandecandelaere, I., Depuydt, P., Nelis, H. J., \& Coenye, T. (2014). Protease production by Staphylococcus epidermidis and its effect on Staphylococcus aureus biofilms. Pathogens and Disease, 70, 321-331. DOI: 10.1111/2049-632X.12133
Vimala, R. (2016). Marine organisms: A potential source of natural antifouling metabolites. International Journal of ChemTech Research, 9, 208-217.

Yebra, D., Kiil, S., \& Dam-Johansen, K. (2004). Antifouling technology: past, present and future steps towards efficient and environmentally friendly antifouling coatings. Progress in Organic Coatings, 75, 104-109. DOI: 10.1016/j.porgcoat.2003.06.001

Zhang, J., Jiang, H., Jiang, J., \& Huang, G. (2016). Isolation and identification of Staphylococcus epidermidis S14 screening extracellular antimicrobial metabolites. American Journal of Biochemistry and Biotechnology, 12, 56-63. DOI: 10.3844/ajbbsp.2016.56.63 